\title{
Refilling of cortical calcium stores in Paramecium cells: in situ analysis in correlation with store-operated calcium influx
}

\author{
I. Mohamed ', M. Husser, I. Sehring, J. Hentschel, C. Hentschel, H. Plattner* \\ Universität Konstanz, Fachbereich Biologie, P.O. Box 5560, 78457 Konstanz, Germany
}

Received 9 October 2002; received in revised form 11 December 2002; accepted 28 January 2003

\begin{abstract}
This is the first thorough study of refilling of a cortical calcium store in a secretory cell after stimulation in which we combined widely different methodologies. Stimulation of dense-core vesicle ("trichocysts") exocytosis in Paramecium involves a Ca ${ }^{2+}$-influx" superimposed to $\mathrm{Ca}^{2+}$-release from cortical stores ("alveolar sacs" (ASs)). In quenched-flow experiments, membrane fusion frequency rose with increasing $\left[\mathrm{Ca}^{2+}\right]_{0}$ in the medium, from $\sim 20-25 \%$ at $\left[\mathrm{Ca}^{2+}\right]_{0} \leq 0.25 \mu \mathrm{M}$ to $100 \%$ at $\left[\mathrm{Ca}^{2+}\right]_{0}$ between 2 and $10 \mu \mathrm{M}$, i.e. close to the range of estimated local intracellular $\left[\mathrm{Ca}^{2+}\right]$ during membrane fusion. Next, we analyzed $\mathrm{Ca}^{2+}$-specific fluorochrome signals during stimulation under different conditions. Treatment with actin-reactive drugs had no effect on $\mathrm{Ca}^{2+}$-signaling. In double trigger experiments, with BAPTA in the second secretagogue application (BAPTA only for stimulation and analysis), the cortical $\mathrm{Ca}^{2+}$-signal (due solely to $\mathrm{Ca}^{2+}$ released from cortical stores) recovered with $t_{1 / 2} \sim 65 \mathrm{~min}$. When ASs were analyzed in situ by X-ray microanalysis after different trigger times $\left(+\mathrm{Ca}^{2+}{ }_{0}\right), t_{1 / 2}$ for store refilling was similar, $\sim 60 \mathrm{~min}$. These values are similar to previously measured ${ }^{45} \mathrm{Ca}^{2+}$-uptake by isolated ASs. In sum we find, (i) exogenous $\mathrm{Ca}^{2+}$ increases exocytosis/membrane fusion performance with $\mathrm{EC}_{50}=0.7 \mu \mathrm{M}$, (ii) $\mathrm{Ca}^{2+}$-signaling in this system is not sensitive to actin-reactive drugs, and (iii) refilling of these cortical calcium stores goes on over hours and thus is much slower than expected.
\end{abstract}

\section{Introduction}

$\mathrm{Ca}^{2+}$ is a second messenger for many processes in eukaryotic cells [1,2], including exocytosis [3-5], from protozoa to mammals. Thereby, $\mathrm{Ca}^{2+}$ may originate from influx from the outside medium and/or from release from internal stores. One possibility is that, in a first step, a secretagogue causes mobilization of $\mathrm{Ca}^{2+}$ from stores located in the cell cortex, superimposed by a $\mathrm{Ca}^{2+}$-influx as a second step [6]-a process called "store-operated $\mathrm{Ca}^{2+}$-influx" (SOC). Signal coupling between the two steps is poorly understood [5-8]. Depletion of stores is followed by refilling via the activity of a SERCA-type $\mathrm{Ca}^{2+}$-pump $[9,10]$, whereby SERCA stands for sarcoplasmic/endoplasmic reticulum $\mathrm{Ca}^{2+}$-ATPase.

Paramecium, which belongs to the ciliated protozoa and thus is closely related to parasitic species, like Plasmod-

\footnotetext{
${ }^{*}$ Corresponding author. Tel.: +7531-88-2228; fax: +7531-88-2245

E-mail addresses: ihabkmohamed@yahoo.com (1. Mohamed), helmut.plattner@uni-konstanz.de (H. Plattner).

'Present address: Department of Zoology, Faculty of Science, Ain-Shams University, Cairo, Egypt.
}

ium and Toxoplasma [11], is an established model system to study exocytosis of dense-core (DC) vesicles called "trichocysts" [12-14]. Meanwhile, we have elucidated in Paramecium some essential features of $\mathrm{Ca}^{2+}$-signaling during exocytosis [15]. Cells can be stimulated for trichocyst exocytosis by the polyamine secretagogue aminoethyldextran (AED) at $1 \mu \mathrm{M}$ concentrations, usually at an extracel-

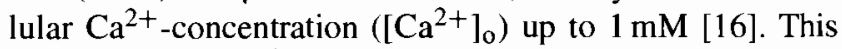
is paralleled by $\mathrm{Ca}^{2+}$-specific fluorochrome signals $[17,18]$. Due to the occurrence of up to 1000 preformed primed exocytosis sites, these cells react by much faster and much more synchronous exocytosis [12.19] than any other DC vesicle system [4]. We have developed a quenched-flow device for quantitative analysis of membrane fusion events by subsequent quantitative freeze-fracture/electron microscope (EM) analysis [20]. Under the standard conditions specified earlier, exocytotic events occur with an apparent $t_{1 / 2}=57 \mathrm{~ms}$, followed by exocytosis-coupled endocytotic membrane resealing $\left(t_{1 / 2}=126 \mathrm{~ms}\right)$, all being accomplished within $350 \mathrm{~ms}[19,20]$. When $\left[\mathrm{Ca}^{2+}\right]_{\mathrm{o}}$ is reduced to a value slightly below intracellular levels at rest $\left(\left[\mathrm{Ca}^{2+}\right]_{i}\right)=65 \mathrm{nM}$ [17] up to $\sim 25$ or slightly more of the preformed exocytotic sites 
can still undergo membrane fusion (this paper, in accordance with previous analyses $[21,22])$. However, increasing $\left[\mathrm{Ca}^{2+}\right]_{0}$ clearly accelerates all steps of the exo-endocytotic cycle [23]. In fact, a significant $\mathrm{Ca}^{2+}$-influx normally accompanies AED-triggered trichocyst exocytosis [24.25]. More scrutinized analyses have established the occurrence of an SOC-type mechanism in Paramecium [18,26], as discussed in more detail in the following.

The regular design of the cortex of a Paramecium cell contains not only regularly arranged trichocyst docking sites for immediate release, but also intermittent "alveolar sacs" (ASs) which encircle each trichocyst (see [14,15]). ASs are flat sacs, $\sim 100 \mathrm{~nm}$ wide, which represent cortical $\mathrm{Ca}^{2+}$-stores $[27,28]$ attached at the cell membrane at a distance of $\sim 15 \mathrm{~nm}$. We found by energy-dispersive $\mathrm{X}$-ray (EDX) microanalysis that up to $80 \%$ of the stored $\mathrm{Ca}^{2+}$ is released upon AED stimulation [29]. Channels involved are only partially identified-they respond to the ryanodine-receptor activators, caffeine and 4-chloro-metacresol (4Cl-m-C) [18], but not to inositol 1,4,5-trisphosphate (InsP $\mathrm{P}_{3}$ ) [28]. ASs possess a SERCA-type pump [30,31] located in that part of the ASs which faces the cell center, as we found by immuno- [32] and green fluorescent protein (GFP)-transfection labeling [33].

In order to re-establish the capability to respond to external stimuli, stores have to be refilled. While there are ample data on refilling of isolated fragments derived from intracellular $\mathrm{Ca}^{2+}$-stores, like ER and SR, measurements in situ have not been reported for any (cortical) store in any secretory system. Here, we have combined widely different methods, including (i) stimulation of synchronous exocytosis, combined with quenched-flow/freeze-fracture analysis at varying $\left[\mathrm{Ca}^{2+}\right]_{o}$, (ii) EDX analysis of total calcium concentrations ([Ca]) contained in ASs at different times after stimulation, (iii) fluorochrome analyses, combined with double trigger experiments. When performed at low $\left[\mathrm{Ca}^{2+}\right]_{0}$, this allows to analyze the contribution selectively of store activation after different refilling times, while the SOC-type component is seen only during stimulation at high $\left[\mathrm{Ca}^{2+}\right]_{0}$. Finally, (iv) we tested the applicability to our system of the hypothesis (derived from higher eukaryotic cells) that F-actin may bind $\mathrm{Ca}^{2+}$ - tores to the plasma membrane and thus mediate an SOC-mechanism [5.7,34-36]. For this purpose, we used drugs shifting the $\mathrm{G} / \mathrm{F}$-actin equilibrium.

\section{Materials and methods}

\subsection{Cell materials}

Wildtype cells strain $7 \mathrm{~S}$ were grown as described [17]. Normally, $\left[\mathrm{Ca}^{2+}\right]_{\mathrm{o}}$ was 1 and $0.5 \mathrm{mM}$ after mixing with the secretagogue, AED, except when indicated that EGTA or BAPTA were added during stimulation, to produce $\left[\mathrm{Ca}^{2+}\right]_{\mathrm{o}}$ $\sim 30 \mathrm{nM}$ (slightly below $\left[\mathrm{Ca}^{2+}\right]_{\mathrm{i}}$ at rest [17]). Note that cells were exposed to $\mathrm{Ca}^{2+}$-chelators only briefly, e.g. for
$0.5 \mathrm{~s}$ during quenched-flow or during simultaneous application with the trigger agent. Under these conditions of low $\left[\mathrm{Ca}^{2+}\right]_{0}$, chelators were removed immediately after stimulation.

\subsection{Dependency of exocytotic membrane fusion on extracellular $\mathrm{Ca}^{2+}$}

For analyzing membrane fusion on freeze-fracture replicas, cells were stimulated with AED in a quenched-flow apparatus [20]. Since this served the detailed analysis in the EM of the dependency of membrane fusion on the availability of extracellular $\mathrm{Ca}^{2+},\left[\mathrm{Ca}^{2+}\right]_{0}$ was quickly adjusted to different levels in the quenched-flow device, by mixing cells for $0.5 \mathrm{~s}$ with EGTA (like in previous experiments $[21,23]$ ) in a first mixing chamber, before AED stimulation was performed for $80 \mathrm{~ms}$ in a second mixing chamber. Further, processing and quantitative analysis were as described previously [23].

\subsection{Double trigger fluorochrome analyses of intracellular $\mathrm{Ca}^{2+}$-transients}

After injection of Fura Red (both from Molecular Probes, Eugene, OR) for double wavelength recording as described [17], exocytosis was stimulated with AED [16], eventually with the addition of BAPTA. In double trigger experiments, cells were stimulated by AED twice. The second time was at different time intervals after the first trigger and after a shortly preceding Fura Red injection. Fluorochrome experiments with the ultrafast $\mathrm{Ca}^{2+}$-chelator, BAPTA, added to the trigger medium were designed to adjust $\left[\mathrm{Ca}^{2+}\right]_{0}$ to $\sim 30 \mathrm{nM}$, i.e. slightly below $\left[\mathrm{Ca}^{2+}\right]_{i}$ at rest [17]. Changes of cortical $\left[\mathrm{Ca}^{2+}\right]_{i}$ in the area closest to AED application were evaluated, also as described $[17,18]$. As mentioned, $\mathrm{Ca}^{2+}$-chelators were eventually added only during stimulation, in quenched-flow experiments $0.5 \mathrm{~s}$ before. The $\mathrm{Ca}^{2+}$-chelator was present in fluorochrome recordings under conditions of low $\left[\mathrm{Ca}^{2+}\right]_{0}$. In double trigger experiments at low $\left[\mathrm{Ca}^{2+}\right]_{0}$, with a time interval of up to $1 \mathrm{~h}$, the chelator was added only during - but not before-the second secretagogue application. No deleterious effects could be recognized during the brief time of $\mathrm{Ca}^{2+}$-chelator application used.

\subsection{EDX analysis of total calcium content in ASs}

For EDX, cells contained in their medium with $\left[\mathrm{Ca}^{2+}\right]_{\mathrm{o}}=$ $1 \mathrm{mM}$ were stimulated for different times with an equal part of $2 \mu \mathrm{M}$ AED (removed in long-time stimulation experiments) in the quenched-flow device $[20,23]$ for cryofixation in melting propane and subsequent freeze-substitution under conditions appropriate to retain $\mathrm{Ca}^{2+}$ in place according to the method of Poenie and Epel [37], modified as previously described $[21,26,29,38]$. Then, cells were embedded in Spurr's resin and semithin sections of $0.5 \mu \mathrm{m}$ were ana- 
lyzed in an analytical EM, type Zeiss/Leo EM912 Omega operated in the STEM mode. Analysis of strictly cross-cut ASs (width $\sim 98 \mathrm{~nm}$ ) was done in the spot mode (diameter at entry: $63 \mathrm{~nm}$, exit: $72 \mathrm{~nm}$ ) and net $\mathrm{Ca} \mathrm{K} \alpha$ peaks were quantified as previously described $[29,38]$.

\subsection{Actin-reactive drugs}

We used the following drugs: cytochalasin B (CytB) from Sigma (Deisenhofen, Germany) and latrunculin A (LatA) as well as jasplakinolide (Jas) from Molecular Probes (Eugene, OR, USA). They were dissolved as a stock solution in DMSO which was diluted to the concentrations indicated, resulting in a DMSO concentration of $<2 \%$ (without side-effects in Paramecium).

Considering the limited knowledge of the effect of such drugs in Paramecium and in order to find out appropriate drug concentrations, we first tested effects on phagocytosis-the best known process requiring F-actin [39-41]. First, Saccharomyces cerevisiae cells were stained by boiling in Congo Red solution. When ingested by Paramecium, a color change to blue indicates phagocytotic internalization. We counted the number of yeast cells phagocytosed within $3 \mathrm{~min}$ by 30 cells after exposure to the respective drugs for the time indicated. Reversibility of phagocytosis inhibition was also tested in wash-out experiments. Second, using appropriate $\mathrm{CytB}$ concentrations, we analyzed corti- cal $\mathrm{Ca}^{2+}$-transients generated by a single AED stimulus at $\left[\mathrm{Ca}^{2+}\right]_{0}==1 \mathrm{mM}$. For digital $\left[\mathrm{Ca}^{2+}\right]_{\mathrm{i}}$ analyses, see the earlier description.

\section{Results}

\subsection{Dependency of exocytotic membrane fusion on} $\left[\mathrm{Ca}^{2+}\right]_{o}$

In the first mixing chamber of the quenched-flow apparatus, we briefly $(0.5 \mathrm{~s})$ adjusted $\left[\mathrm{Ca}^{2+}\right]_{o}$ to values between $30 \mathrm{nM}$ and $0.5 \mathrm{mM}$, followed by AED stimulation for $80 \mathrm{~ms}$ in the second mixing chamber. This is the time normally required to accomplish membrane fusion at all potential trichocyst exocytosis sites [20]. Subsequent quantitative EM evaluation of freeze-fracture replicas is presented in Fig. 1. Up to $\left[\mathrm{Ca}^{2+}\right]_{\mathrm{o}}=0.25 \mu \mathrm{M}$, a basal level of $22-26 \%$, average $\sim 25 \%$, of sites competent for exocytosis (as recognizable by their ultrastructural organization [23]) undergo fusion. From $>0.25 \mu \mathrm{M}$ on the frequency of fusion events increases to near plateau values at $\left[\mathrm{Ca}^{2+}\right]_{0}=2 \mu \mathrm{M}$, with only $14 \%$ additional increase up to $\left[\mathrm{Ca}^{2+}\right]_{0}=0.5 \mathrm{mM}$. Half-value of $\left[\mathrm{Ca}^{2+}\right]_{0}$ for the increase is 0.6 and $0.7 \mu \mathrm{M}$, respectively, for the range of $\left[\mathrm{Ca}^{2+}\right]_{0}$ between 0.25 and $2 \mu \mathrm{M}$, and for the range between 0.25 and $0.5 \mathrm{mM}$, respectively (Fig. 1).

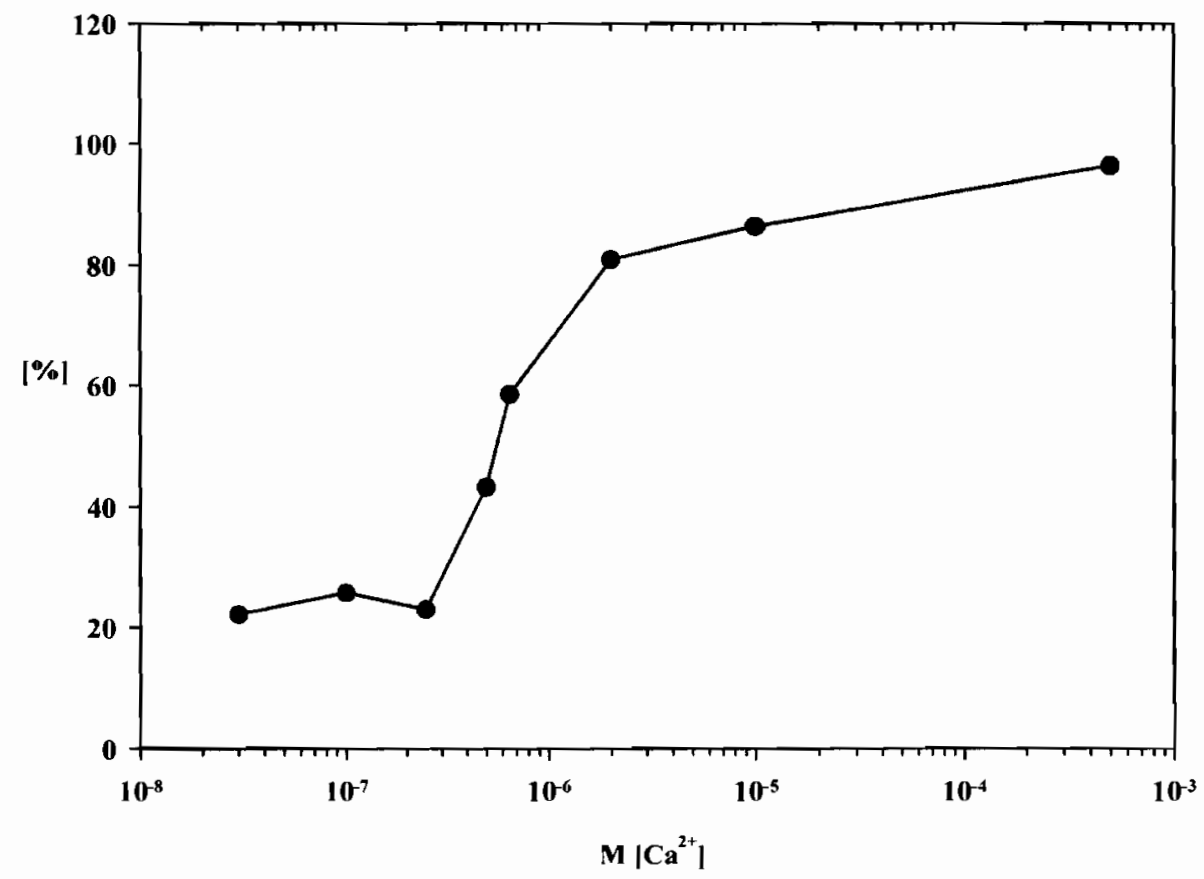

Fig. 1. Increase of exocytotic membrane fusion with increasing $\left[\mathrm{Ca}^{2+}\right]_{0}$ during $\mathrm{AED}$ stimulation. In the quenched-flow apparatus, $\left[\mathrm{Ca}{ }^{2+}\right]_{0}$ has been adjusted to different values $0.5 \mathrm{~s}$ before and during $80 \mathrm{~ms}$ AED stimulation, by adding EGTA at different concentrations (yielding the calculated [Ca $\left.{ }^{2+}\right]_{0}$ values indicated; see "Section 2" and [23]). EM analysis of typical freeze-fracture/ultrastructural transformations is presented as medians of trichocyst docking sites described in Refs. $[20,23]$. Note that a fairly constant proportion $(\sim 25 \%)$ of membrane fusion occurs already at very low [Ca $\left.{ }^{2+}\right]_{0}$, increasing from $\sim 0.25 \mu \mathrm{M}$ on to a plateau at $>2 \mu \mathrm{M}$. Number of cells $(N)$ and of fusion sites $(n)$ analyzed per data point are, in the order of rising $\left[\mathrm{Ca}{ }^{2+}\right]_{0}$ indicated on the basis, as follows: $N=28,24,29,25,30,44,29$, and $32 ; n=460,443,394,548,806,410$, and $636\left(\right.$ from $\left[\mathrm{Ca}^{2+}\right]_{0}=3 \times 10^{-8}-5 \times 10^{-4} \mathrm{M}^{-}$. 


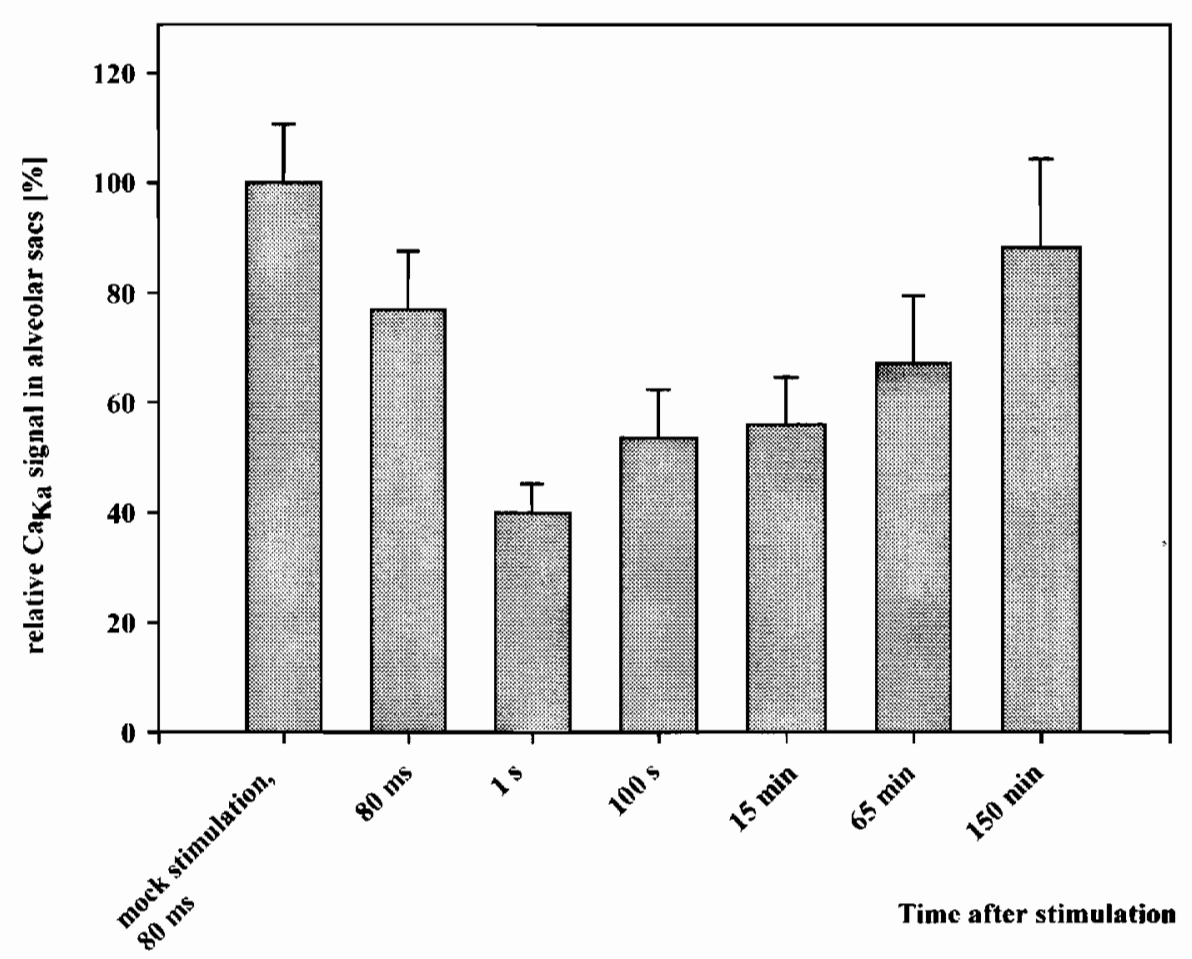

Fig. 2. Relative intensity of $\mathrm{Ca} \mathrm{K} \alpha$ signals (normalized to control $=80 \mathrm{~ms}$ mock stimulation with buffer), corresponding [Ca], recorded in ASs by EDX at different times after AED-stimulated exocytosis. Values for controls and 150 min refilling are significantly different from value after $80 \mathrm{~ms}$ stimulation $(P<0.05)$; bars $=$ standard error of the mean (S.E.M.). Note that $\mathrm{Ca}^{2+}$-release, which is only partial, is followed by rather slow refilling. From left to right: $N$ (cells analyzed) $=4,4,6,6,5,4$, and $4 ; n$ (ASs analyzed) $=16,26,24,30,40,30$, and 28 .

\subsection{Analysis of AS refilling by EDX}

The state of filling and refilling after stimulation could be directly monitored by quantitative evaluation of the Ca $\mathrm{K} \alpha$ net peaks contained in the EDX spectra recorded in the spot mode. These values represent concentrations of total calcium, $[\mathrm{Ca}]$, i.e. free and bound. Data were collected from ASs in many cells, as indicated in Fig. 2. In agreement with previous analyses, AED caused rapid depletion of ASs of their stored calcium, from a calibrated original value of total $[\mathrm{Ca}]=43 \mathrm{mM}$ in ASs before stimulation to $\sim 25 \%$ residual $[\mathrm{Ca}$ ] after $1 \mathrm{~s}$ AED stimulation [29]. After full stimulation, AED was removed and cells were kept under "normal" culture conditions ( $+\mathrm{Ca}^{2+}{ }_{0}$, see "Section 2"). Aliquots were subjected to fast-freezing, freeze-substitution, and EDX analysis at different times after AED stimulation. Under these conditions, [Ca] in AS was seen to increase with a half-time of $\sim 60 \mathrm{~min}$, as one can derive from Fig. 2 .

\subsection{Double trigger experiments and fluorochrome analysis}

We have compared local cortical fluorochrome signals achieved in Fura Red injected cells at the site of AED application with an extracellular micropipette (see [17]), as documented in Fig. 3. Before this step, cells in suspension had been fully stimulated by AED at $\left[\mathrm{Ca}^{2+}\right]_{0}=1 \mathrm{mM}$, AED was removed and Fura Red had been injected imme- diately before cells were immobilized for local application of a second AED stimulus at different time intervals after the first stimulus. The second stimulus was applied under two different conditions, (i) at $\left[\mathrm{Ca}^{2+}\right]_{\mathrm{o}}=1 \mathrm{mM}$, in experiments further on designated " $+\mathrm{Ca}^{2+}{ }_{0}$ " (Fig. 3a-e), and with $1 \mathrm{mM}$ BAPTA added to yield $\left[\mathrm{Ca}^{2+}\right]_{\mathrm{o}} \sim 30 \mathrm{nM}$, designated "-Ca ${ }^{2+}{ }_{0}$ " (Fig. $3 \mathrm{f}-\mathrm{h}$ ). Note that $\left[\mathrm{Ca}^{2+}\right]_{\mathrm{i}}$ in unstimulated cells is $\sim 65 \mathrm{nM}$ [17]. Therefore, any SOC-type mechanism can occur only in experiments $+\mathrm{Ca}^{2+}{ }_{0}$, but not in those $-\mathrm{Ca}^{2+}{ }_{\mathrm{o}}$. We also analyzed the time required to achieve peak values of cortical $\left[\mathrm{Ca}^{2+}\right]_{i}$ (see the following description).

It should be noted that only AED stimulation $-\mathrm{Ca}^{2+}$ o can give information, though indirect, on the extent of store refilling. Experiments $+\mathrm{Ca}^{2+}$ o have also been included in order to control any potential side-effects of double triggering, such as any possible refractoriness of $\mathrm{Ca}^{2+}$-influx channels, and thus to obtain some additional information on the largely unknown mechanisms governing SOC-type responses. We emphasize again the brief time of $\mathrm{Ca}^{2+}$-chelator application, without any recognizable side-effects (see "Section 2").

Let us first consider experiments of the type " $+\mathrm{Ca}^{2+}$ ". Control experiments (one AED stimulus only, $+\mathrm{Ca}^{2+}{ }_{0}$ ), show a swift increase of cortical $\mathrm{Ca}^{2+}$-signals, with a peak at $1.5 \mathrm{~s} \pm 0.0$ (standard error of the mean (S.E.M.)) after AED stimulation (Fig. 3a). Considering the time required for filter change $(0.5 \mathrm{~s})$ in double wavelength recordings, the real rise time may be smaller. In double trigger experiments, with an increasing time interval between the first and the 

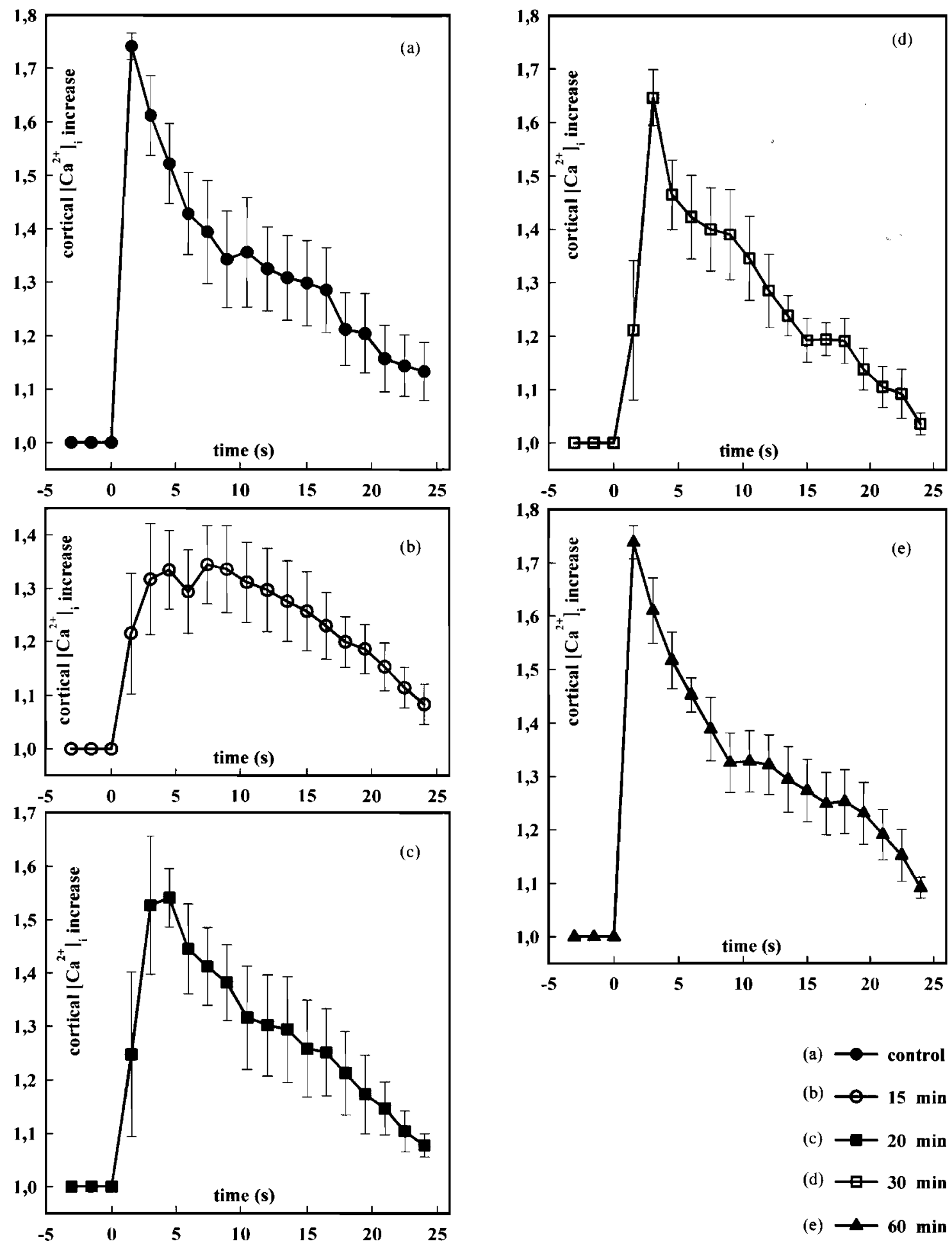

Fig. 3. Time course of fluorochrome signals recorded in the cortex of Fura Red-loaded cells at the site of AED stimulation (at time 0). Abscissa: time scale $(\mathrm{s})$; ordinate: relative $\left[\mathrm{Ca}^{2+}\right]_{i}$-signal recorded in cell cortex at stimulation site. Panels a-e were obtained under conditions " $+\mathrm{Ca}{ }^{2+}{ }_{0}$ ", after one AED stimulus only $(0 \mathrm{~min})$, and after double triggering in $15,20,30$. and $60 \mathrm{~min}$ intervals, respectively. Panels $\mathrm{f}-\mathrm{h}$ were obtained under conditions "- $\mathrm{Ca}^{2+} 0 "$ (with BAPTA in the AED trigger medium), also after one AED stimulus only ( 0 min), and after double stimulation in 15 min and 60 min intervals, respectively. Bars $=$ S.E.M.; missing S.E.M. bars means no statistical fluctuations recorded. Number of cells analyzed per data point $N=5$. 


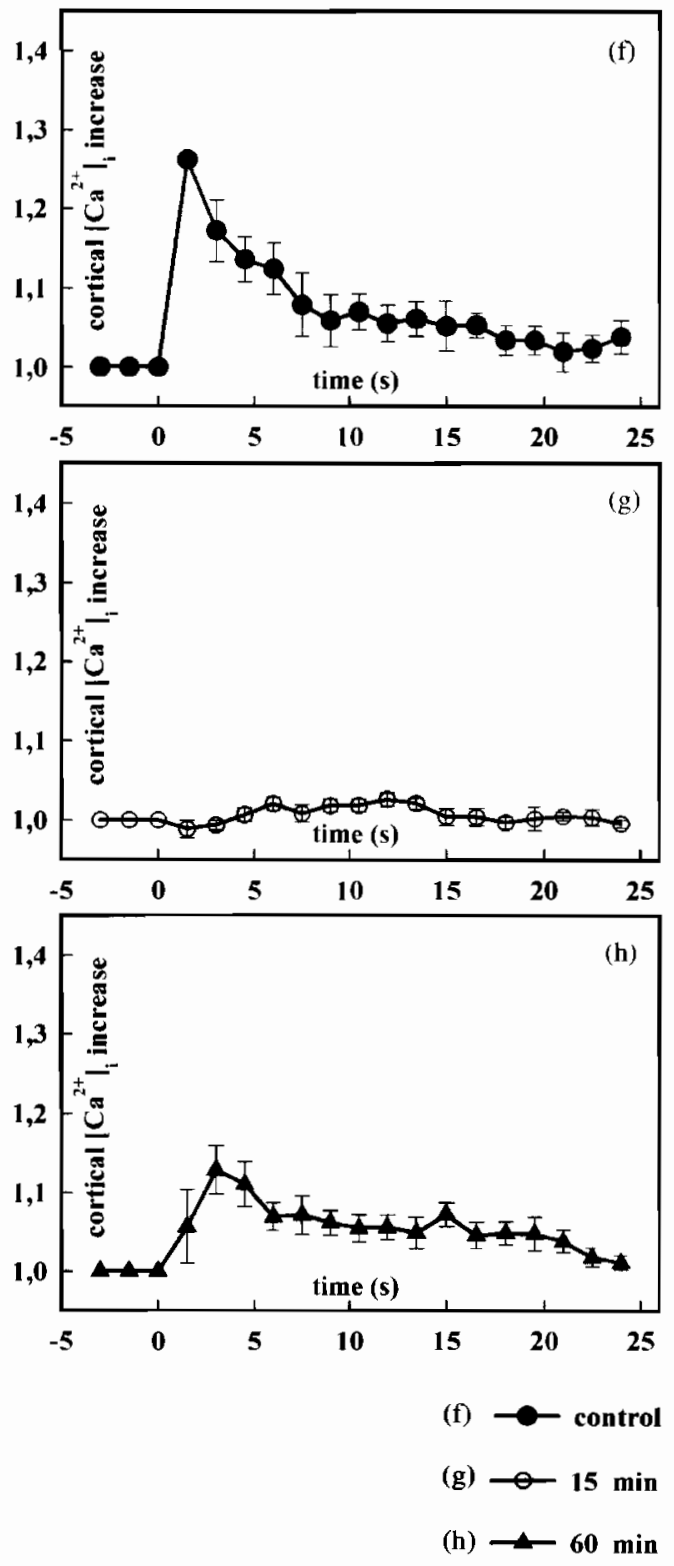

Fig. 3. (Continued).

second trigger, the cortical $\mathrm{Ca}^{2+}$-signal increase becomes more and more pronounced, but the rise time becomes longer than recorded in controls. In detail, the relative fluorescence signal increase was $1.74 \pm 0.03$ for the control (one stimulus), $1.43 \pm 0.04$ (15 min interval between first and second stimulus), $1.65 \pm 0.04(20 \mathrm{~min}), 1.68 \pm 0.03(30 \mathrm{~min})$, and $1.74 \pm 0.03(60 \mathrm{~min})$. Rise times were $\leq 1.5 \mathrm{~s} \pm 0.0$ for the control (one stimulus), $3.9 \mathrm{~s} \pm 1.0$ ( $15 \mathrm{~min}$ interval), $3.0 \mathrm{~s} \pm 0.5(20 \mathrm{~min}), 2.7 \mathrm{~s} \pm 0.3(30 \mathrm{~min})$, and $\leq 1.5 \mathrm{~s} \pm 0.0$ $(60 \mathrm{~min})$. We want to comment these data as follows. The shortest double trigger experiment technically possible was with a $15 \mathrm{~min}$ interval. This is the minimum time required for handling, i.e. wash-out of AED, fluorochrome injection, and immobilization for the second AED stimulation and subsequent signal recording. When the second AED stimu- lus followed in a $15 \mathrm{~min}$ interval after the first stimulus, the signal generated was much weaker and it rose less rapidly than in controls (Fig. 3b). Then, with increasing intervals between the two stimuli, the $\left[\mathrm{Ca}^{2+}\right]_{\mathrm{i}}$ peak achieved increases (Fig. 3a-e) and rise time to peak value decreases.

Fig. $3 \mathrm{f}-\mathrm{h}$ contain results from experiments of the type " $-\mathrm{Ca}^{2+}{ }_{0}$ ". (Recall that $\mathrm{Ca}^{2+}{ }_{0}$ was chelated only during the second AED application and that $1.5 \mathrm{~s}$ is again the minimum recording time due to filter change.) The relative fluorescence signal increase achieved was $1.27 \pm 0.005$ (control, only one AED + BAPTA application), $1.03 \pm 0.000$ (15 min interval between AED and AED+BAPTA application), and $1.13 \pm 0.03$ ( $60 \mathrm{~min}$ interval). The rise time was $\leq 1.5 \mathrm{~s} \pm 0.0$, $7.5 \mathrm{~s} \pm 1.6(15 \mathrm{~min})$, and $2.4 \mathrm{~s} \pm 0.4(60 \mathrm{~min}$ interval between AED and AED + BAPTA application). In summary, control cells, stimulated by AED + BAPTA, yield only $35 \%$ of the cortical $\mathrm{Ca}^{2+}$-signal when compared with stimulation experiments under conditions $+\mathrm{Ca}^{2+}{ }_{0}$. Under conditions $-\mathrm{Ca}^{2+}{ }_{0}$, the signal generated by a second AED stimulus after $15 \mathrm{~min}$ is extraordinarily small $\left(7 \%\right.$ of that $+\mathrm{Ca}^{2+}{ }_{0}$ ). Half of the signal of controls at $-\mathrm{Ca}^{2+}$ o was found when the time interval between the two stimuli was $65 \mathrm{~min}$.

Comparison of the data " $+\mathrm{Ca}^{2+}{ }_{\mathrm{o}}$ " and " $-\mathrm{Ca}^{2+}{ }_{\mathrm{o}}$ " contained in Fig. 3 reveals some additional aspects. In " $+\mathrm{Ca}^{2+}$ o" experiments, there is a strong $\mathrm{Ca}^{2+}$-influx component in controls which, in double trigger experiments, slowly recovers with increasing time between the two stimuli. Under conditions "- $-\mathrm{Ca}^{2+}$ o", the $\mathrm{Ca}^{2+}$-signal is small in single trigger experiments (controls, $0 \mathrm{~s}$ ). In $15 \mathrm{~min}$ double trigger experiments, there is considerable response under conditions " $+\mathrm{Ca}^{2+}$ o", but a negligibly small one under conditions " $-\mathrm{Ca}^{2+} \mathrm{o}$ ". Evidently, $15 \mathrm{~min}$ is much too short for any substantial refilling of ASs. Since at $-\mathrm{Ca}^{2+}{ }_{\mathrm{o}}$, the signal clearly reaches $50 \%$ after $65 \mathrm{~min}$, this indicates the half-time of store refilling. This signal increase parallels the store refilling determined directly by EDX analysis (Fig. 2) -an alternative approach based on a widely different principle.

\subsection{Effects of actin-reactive drugs on SOC}

In order to elucidate any effect of cortical F-actin, as reported for higher eukaryotes (see "Section 1"), we first tested in pilot experiments the effects of different F-actin de-stabilizing (CytB, LatA) and stabilizing (Jas) drugs on phagocytosis (data not shown). We considered this important taking into account the aberrant or even missing effect of many drugs in lower eukaryotes. Phagocytosis was taken as a positive control since in Paramecium this is the best known process requiring F-actin [39-43]. We also tested reversibility to exclude toxic side-effects. Concentrations of CytB required are relatively high, just as in previous work with paramecia, when different cell functions had been analyzed $[39,44,45]$. We achieved $50 \%$ inhibition with CytB at $100 \mu \mathrm{g} / \mathrm{ml}, 30 \mathrm{~min} ; 90$ and $95 \%$ inhibition was achieved with $200 \mu \mathrm{g} / \mathrm{ml}$ applied for 30 and $60 \mathrm{~min}$, respectively. To ascertain specificity even more, we also used some newly 
Table 1

Effect of CytB $(200 \mu \mathrm{g} / \mathrm{ml})$ on $\left[\mathrm{Ca}^{2+}\right]_{\mathrm{i}}$ fluorescence signal generated in the cell cortex upon AED stimulation

\begin{tabular}{lc}
\hline Duration of CytB treatment $(\min )$ & Relative $\left[\mathrm{Ca}^{2+}\right]_{\mathbf{i}}$ increase (\%) \\
\hline 0 (control) & $100 \pm 3$ \\
30 & $96 \pm 4$ \\
60 & $106 \pm 2$ \\
$60 \rightarrow 90$ (wash-out) & $97 \pm 1$
\end{tabular}

Controls $=100 \% \pm$ standard deviation. Number of cells analyzed, $N=5$ per data point.

available drugs, Jas and LatA, respectively. They all inhibited phagocytosis at relatively high concentrations. All these effects were fully reversible in wash-out experiments; for instance, after application of CytB at $200 \mu \mathrm{g} / \mathrm{ml}$ for $60 \mathrm{~min}$, the time required for 50 and $100 \%$ recovery was 40 and $90 \mathrm{~min}$, respectively. This made us confident to see any potential effect on $\mathrm{Ca}^{2+}$-signaling, if it would exist, without any side-effects.

Using routine ultrathin section electron microscopy, we first analyzed the effect of $\mathrm{CytB}$ on the positioning not only of ASs but also of mitochondria-another organelle of relevance for $\mathrm{Ca}^{2+}$-signaling [15]. Yet, no effect on their positioning was found in quantitative evaluations (data not shown). Secondly, we analyzed fluorochrome signals generated by $\mathrm{AED}$ after $\mathrm{CytB}$ treatment under conditions " $+\mathrm{Ca}^{2+}$ ". As documented in Table 1, we found no change in $\mathrm{Ca}^{2+}$-signaling when $\mathrm{CytB}$-treated cells were stimulated with AED, even under conditions when phagocytosis was considerably inhibited.

\section{Discussion}

\subsection{Relevance of $\mathrm{Ca}^{2+}{ }_{o}$ for maximal exocytotic response}

Previously, we had found with wildtype cells that mobilization of $\mathrm{Ca}^{2+}$ from internal (cortical) stores can activate only $\sim 22-37 \%$ of trichocyst docking sites to undergo membrane fusion [21,22]. While this is in agreement with the data presented here, we now have analyzed in more detail the dependency of membrane fusion on $\left[\mathrm{Ca}^{2+}\right]_{0}$ (Fig. 1, Table 3). We find that maximal response occurs with $\left[\mathrm{Ca}^{2+}\right]_{0}$ close to, or slightly above the $\sim 5 \mu \mathrm{M}$ estimated at the activation sites $[15,17]$. Above a threshold level of $\left[\mathrm{Ca}^{2+}\right]_{0}$, i.e. $>0.25 \mu \mathrm{M}$, the exocytotic membrane fusion response steadily increases, with half-maximal activation at $\left[\mathrm{Ca}^{2+}\right]_{\mathrm{o}}=0.7 \mu \mathrm{M}$ (Table 2 ).

Is $\mathrm{Ca}^{2+}$ the relevant ion for AED stimulation or can the phenomena observed be explained merely by the charge of the secretagogue? Our answer is clearly in favor of the relevance of $\mathrm{Ca}^{2}+$ because of different reasons. (i) The polycationic compound, AED, can act as a secretatogue only in conjunction with $\mathrm{Ca}^{2+}$, as reviewed in Ref. [15], or with the quite similar $\mathrm{Sr}^{2+}$ ion [29], but not with $\mathrm{Mg}^{2+}$ which is inhibitory [46]. (ii) Injection of highly selective $\mathrm{Ca}^{2+}$-buffers
Table 2

Characteristics of alveolar sacs (ASs), $\left[\mathrm{Ca}^{2+}\right]_{i}$ required for exocytosis, $\mathrm{Ca}^{2+}$-release from $\mathrm{ASs}$, and refilling of $\mathrm{ASs}$ in situ (following maximal AED stimulation) in comparison to in vitro ${ }^{45} \mathrm{Ca}^{2+}$ uptake by isolated $A S$

Total calcium concentration [Ca] in AS $43 \mathrm{mM} \mathrm{[38]}$

$\mathrm{Ca}^{2+}$ released from $\mathrm{AS}$

upon stimulation (l s)

$\left[\mathrm{Ca}^{2+}\right]_{0}$ required for SOC-type effect

Minimum effect

Half-maximal effect

Maximal effect

Local $\left[\mathrm{Ca}^{2+}\right]_{\mathrm{i}}$ at maximal stimulation

Refilling half-time

EDX

Double trigger experiments + BAPTA

${ }^{45} \mathrm{Ca}^{2+}$-uptake in vitro

$80 \%[29]$

$80 \%[29$

$0.25 \mu \mathrm{M}$ (this paper)

$0.7 \mu \mathrm{M}$ (this paper)

$\sim 2-10 \mu \mathrm{M}$ (this paper)

$\sim 5 \mu \mathrm{M}[17]$

$\sim 60$ min (this paper)

$\sim 65 \mathrm{~min}$ (this paper)

$\sim 60 \mathrm{~min}[56]^{\mathrm{b}}$

a Assuming logarithmic increase.

${ }^{\mathrm{b}}$ Derived from extensive series presented as Fig. 3 in Länge et al. [57].

inhibits trichocyst exocytosis [17]. (iii) Neither depolarization nor hyperpolarization can cause trichocyst exocytosis [47].

Are our current data compatible with the SOC-mechanism mentioned? An SOC-mechanism occurring during stimulated trichocyst exocytosis in Paramecium has been implied indirectly from quenched-flow/freeze-fracture analysis [21] and from whole cell-patch recording of $\mathrm{Ca}^{2+}$-activated currents [47]. More stringent evidence came from work with a double mutant devoid of any ${ }^{45} \mathrm{Ca}^{2+}$-influx [24], showing generation of cytosolic fluorochrome signals and decreasing $\mathrm{CaK} \alpha$ net peaks in EDX analyses after AED stimulation [26].

Storage of $\mathrm{Ca}^{2+}$ in ASs depends on the presence of and binding to a calsequestrin-like high capacity/low affinity $\mathrm{Ca}^{2+}$-binding protein [48]. $\mathrm{Ca}^{2+}$ can rapidly dissociate, and according to EDX data, $\sim 80 \%$ are released during $1 \mathrm{~s} \mathrm{AED}$ stimulation [29]. While local $\left[\mathrm{Ca}^{2+}\right]_{i}$ at exocytosis sites can only indirectly and roughly be estimated, a balance calculation of total $\mathrm{Ca}^{2+}$-fluxes reveals that mobilization from ASs and SOC-type influx may contribute about equally to $\mathrm{Ca}^{2+}$-signaling [15]. Clearly both components have to act in concert to achieve optimal response. Our present fluorochrome analyses (Fig. 3) clearly support this concept for the following reasons. Double trigger experiments, conditions " $+\mathrm{Ca}^{2+}$ o", yield much higher signals upon a second AED stimulation at different time intervals $(15,20,30$, and $60 \mathrm{~min}$ ) than under conditions "- $\mathrm{Ca}^{2+}$ ". When the two conditions, $+\mathrm{Ca}^{2+}{ }_{0}$ and $-\mathrm{Ca}^{2+}{ }_{0}$, are compared, values obtained with double trigger intervals of $O$ (control), 15, and $60 \mathrm{~s}$ under " $-\mathrm{Ca}^{2+} \mathrm{o}$ " conditions represent 35,7 , and $18 \%$, respectively, of those obtained under " $+\mathrm{Ca}^{2+}$ o" conditions (see "Section 3"). The very low value at $15 \mathrm{~min},-\mathrm{Ca}^{2+}{ }_{0}$, is clearly expected if an SOC-type mechanism occurs. The same holds for the proportion of the influx component which is lowest at $15 \mathrm{~min}$ in the series " $+\mathrm{Ca}^{2+}$ ", but in relative terms it is highest when put in relation to the signal under "- $\mathrm{Ca}^{2+}$ o" conditions, also at $15 \mathrm{~min}$. This agrees well with the SOC-mechanism described. 
How do we explain the relative low signal in $15 \mathrm{~min}$ double trigger experiments at " $+\mathrm{Ca}^{2+}$ " " and the relatively long time required to reach peak values at " $-\mathrm{Ca}^{2+}{ }_{0}$ "? A tentative explanation could be the refractoriness of the $\mathrm{Ca}^{2+}$-influx channels involved, although this is not known, e.g. for the unspecific cation-conducting channels of the type described by Saitow et al. [49] which we had envisaged as candidates [18].

Another aspect of our work is the absence of any effects of "actin-reactive" drugs on SOC-type signaling in Paramecium, in contrast to several reports on higher eukaryotic cells [5,7,34-36]. We believe that in Paramecium, linkage of ASs to the plasma membrane is unlikely due to F-actin. Although we know that some F-actin does occur in the cell periphery [40,41], its precise localization remains to be established. Any potential contribution to positioning of SERCA molecules and possibly of cation exchangers relative to each other [50], as well as to the total $\mathrm{Ca}^{2+}{ }_{\mathrm{i}}$-balance remain unknown so far.

\subsection{Refilling of ASs}

During $\mathrm{Ca}^{2+}$-signaling, as in other cells, a very large excess of total calcium is sweeping over the cell cortex into the Paramecium cell [15]. Before re-uptake into ASs, $\mathrm{Ca}^{2+}$ will be bound to cytosolic $\mathrm{Ca}^{2+}$-binding proteins with high $\mathrm{Ca}^{2+}$-binding capacity [51]. Gradual dissociation allows for slowly ongoing transfer from the cytosolic compartment into stores.

How fast are stores refilled with $\mathrm{Ca}^{2+}$ ? Most publications consider only changes of free $\mathrm{Ca}^{2+},\left[\mathrm{Ca}^{2+}\right]$, in stores. Fluorochrome analyses show recovery of $\left[\mathrm{Ca}^{2+}\right]$ within the order of magnitude of $30 \mathrm{~s}$ in the SR smooth muscle [52] to 1-3 min in the SR of skeletal muscle [53], when measured in vitro. To assess refilling of stores, measurements of total calcium concentrations [Ca] is required. Such data are essentially restricted to the SR of muscle cells. EDX analysis of [Ca] in SR of skeletal muscle, which also operates by an SOC-type mechanism [1,2,10,54], revealed that $\sim 40 \%$ are released during normal contraction activity and $\sim 60 \%$ dewing tetanic stimulation [55]. The percentage of $\mathrm{Ca}^{2+}$-released is comparable to what we found during one cycle of trichocyst exocytosis [29]. Also [Ca] values in stores before imulation are quite similar in the two systems, i.e. $43 \mathrm{mM} i \mathrm{iSs}$ [38] and $33 \mathrm{mM}$ in skeletal muscle SR [54], both estimated on the basis of wet weight. However, refilling times evidently are widely different between the SR of skeletal muscle and our system. How can this be explained?

In a more scrutinized analysis, we would have to consider two very different types of $\mathrm{Ca}^{2+}$-uptake into ASs, a fast and a slow component. (i) In quenched-flow/EDX experiments, we found that $\mathrm{Ca}^{2+}$ or $\mathrm{Sr}^{2+}$ as a substitute (with clearly resolved $\mathrm{K} \alpha$ energy) enters $\mathrm{ASs}$ within 1 s, i.e. already during ongoing exocytosis and release of endogenous $\mathrm{Ca}^{2+}$ [29]. (ii) As a candidate for the long-term re-uptake mechanism analyzed in the present paper, we have to con- sider the SERCA-pump of ASs [30,31]. This is localized specifically in that part of ASs which faces the interior of the cell, i.e. the "inner AS membrane" [32]. For aspect (i), some authors envisage a $\mathrm{Na}^{+} / \mathrm{Ca}^{2+}$ exchanger system, e.g. for the $\mathrm{SR}$ in smooth muscle cells (as discussed by Hellstrand [56]), but no information along these lines exists for Paramecium. In striated muscle cells, rapid re-uptake of $\mathrm{Ca}^{2+}$ into the $\mathrm{SR}$ is mediated by mechanism (ii), i.e. by its SERCA activity. In the SR, this is due to higher activity and to the much larger membrane area containing SERCA molecules (in the extensive longitudinal system [9]) as compared to the area containing $\mathrm{Ca}^{2+}$-release channels (restricted to the relatively small terminal cisternae [53]). This microanatomical principle, small release versus large uptake area, is not applicable to Paramecium [32] and concomitantly refilling by SERCA activity is slow (see Table 2). Therefore, over longer periods after AED stimulation, $\mathrm{Ca}^{2+}$ in $\mathrm{ASs}$ is replenished only slowly by the activity of their SERCA-type $\mathrm{Ca}^{2+}$-pump/ATPase [30,31]. The half-time of $60-65 \mathrm{~min}$ for refilling, as reported in the present paper, is the same as that determined for ${ }^{45} \mathrm{Ca}^{2+}$-uptake by isolated ASs in vitro $\left(t_{1 / 2} \sim 60 \mathrm{~min}\right),[56]$. In total, $\mathrm{Ca}^{2+}$-pumping activity of $\mathrm{ASs}$ from Paramecium [56] is much slower than that of SR from skeletal muscle [9].

\subsection{Implications for the Paramecium system and outlook to related protozoan species}

In contrast to the extensive genome cloning, little is known about $\mathrm{Ca}^{2+}$-signaling in related pathogenic species which also contain cortical alveoli (see "Section 1"). Their invasion mechanism involves sequential exocytotic processes which in part depend on $\mathrm{Ca}^{2+}$ [58]. Our analysis may facilitate further insight into this system. In Paramecium, rapid trichocyst exocytosis serves defense against predators, as first shown by Harumoto and Miyake [59] and then by Knoll et al. [60]. After total depletion of trichocysts, re-installation of a complete new set requires up to $10 \mathrm{~h}[12,61]$. Even though $\mathrm{Ca}^{2+}$-re-uptake is slow, sufficient $\mathrm{Ca}^{2+}$ will be available in ASs as new trichocysts are gradually inserted.

\section{Acknowledgements}

We thank Dr. Norbert Klauke, University of Glasgow, for helpful comments. We gratefully acknowledge financial support by the Deutsche Forschungsgemeinschaft (DFG) Project P178/15.

\section{References}

[1] M.J. Berridge, P. Lipp, M.D. Bootman. The versatility and universality of calcium signalling, Nat. Rev. Cell Biol. 1 (2000) 11-21

[2] A. Tepikin (Ed.), Calcium Signalling. 2nd ed., Oxford University Press, Oxford, 2001, p. 230 
[3] E. Neher, Vesicle pools and $\mathrm{Ca}^{2+}$ microdomains: new tools for understanding their roles in neurotransmitter release, Neuron 20 (1998) 389-399.

[4] H. Kasai, Comparative biology of $\mathrm{Ca}^{2+}$-dependent exocytosis: implications of kinetic diversity for secretory function, Trends Neurosci. 22 (1999) 88-93.

[5] A.C. Elliott, Recent developments in non-excitable cell calcium entry, Cell Calcium 30 (2001) 73-93.

[6] J.W. Putney, Channelling calcium, Nature 410 (2001) 648-649.

[7] J.A. Rosado, S.O. Sage. The actin cytoskeleton in store-mediated calcium entry, J. Physiol. 526 (2000) 221-229

[8] M.D. Bootman. M.J. Berridge, H.L. Roderick, Activating calcium release through inositol 1.4,5-trisphosphate receptors without inositol 1,4,5-trisphophate. Proc. Natl. Acad. Sci. U.S.A. 99 (2002) 7320 7322.

[9] M.W. Berchtold, H. Brinkmeier. M. Müntener, Calcium ion in skeletal muscle: its crucial role for muscle function, plasticity, and disease, Physiol. Rev. 80 (2000) 1215-1265.

[10] E. Carafoli, J. Krebs (Eds.), Calcium Homeostasis, Springer-Verlag, Berlin, New York, 2000, p. 188.

[11] P. Dessen, M. Zagulski, R. Gromadka, H. Plattner, et al., Paramecium genome survey: a pilot project, Trends Genet. 17 (2001) 306-308.

[12] H. Plattner, G. Knoll. R. Pape, Synchronization of different steps of the secretory cycle in Paramecium tetraurelia: trichocyst exocytosis, exocytosis-coupled endocytosis, and intracellular transport, in: $\mathbf{H}$. Plattner (Ed.), Membrane Traffic in Protozoa, JAI Press, Greenwich, CT, USA, London, UK, 1993, pp. 123-148.

[13] L. Vayssié, F. Skouri, L. Sperling, J. Cohen, Molecular genetics of regulated secretion in Paramecium, Biochimie 82 (2000) 269-288.

[14] H. Plattner, My favorite cell-Paramecium, BioEssays 24 (2002) 649-658

[15] H. Plattner, N. Klauke, Calcium in ciliated protozoa: sources, regulation, and calcium-regulated cell functions. Int. Rev. Cytol. 20I (2001) 115-208.

[16] H. Plattner, R. Stürzl, H. Matt, Synchronous exocytosis in Paramecium cells. IV. Polyamino-compounds as potent trigger agents for repeatable trigger-redocking cycles, Eur. J. Cell Biol. 36 (1985) 32 37

[17] N. Klauke, H. Plattner, lmaging of $\mathrm{Ca}^{2+}$ transients induced in Paramecium cells by a polyamine secretagogue, J. Cell Sci. 110 (1997) 975-983

[18] N. Klauke, M.-P. Blanchard, H. Plattner, Polyamine triggering of exocytosis in Paramecium involves an extracellular $\mathrm{Ca}^{2+} / /$ polyvalent cation)-sensing receptor, subplasmalemmal $\mathrm{Ca}$-store mobilization and store-operated $\mathrm{Ca}^{2+}$ influx via unspecific cation channeis, J. Membr. Biol. 174 (2000) 141-156.

[19] H. Plattner, G. Knoll, C. Erxleben, The mechanics of biological membrane fusion. Merger of aspects from electron microscopy and patch-clamp analysis, J. Cell Sci. 103 (1992) 613-618.

[20] G. Knoll, C. Braun, H. Plattner, Quenched flow analysis of exocytosis in Paramecium cells: time course, changes in membrane structure, and calcium requirements revealed after rapid mixing and rapid freezing of intact cells, J. Cell Biol. 113 (1991) 1295-1304

[21] G. Knoll, A. Grässle, C. Braun, W. Probst, B. Höhne-Zell, H. Plattner, A calcium influx is neither strictly associated with nor necessary for exocytotic membrane fusion in Paramecium cells, Cell Calcium 14 (1993) 173-183

[22] C. Erxleben, N. Klauke, M. Flötenmeyer, M.-P. Blanchard, C. Braun, H. Plattner, Microdomain $\mathrm{Ca}^{2+}$ activation during exocytosis in Paramecium cells. Superposition of local subplasmalemmal calcium store activation by local $\mathrm{Ca}^{2+}$ influx, J. Cell Biol. 136 (1997) 597-607.

[23] H. Plattner, C. Braun, J. Hentschel, Facilitation of membrane fusion during exocytosis and exocytosis-coupled endocytosis and acceleration of "ghost" detachment in Paramecium by extracellular calcium. A quenched-flow/freeze-fracture analysis, J. Membr. Biol. 158 (1997) $197-208$.
[24] D. Kerboeuf, J. Cohen, A $\mathrm{Ca}^{2+}$ influx associated with exocytosis is specifically abolished in a Paramecium exocytotic mutant. J. Cell Biol. 111 (1990) 2527-2535.

[25] G. Knoll. D. Kerboeuf. H. Plattner, A rapid calcium influx during exocytosis in Paramecium cells is followed by a rise in cyclic GMP within $1 \mathrm{~s}$, FEBS Lett. 304 (1992) 265-268.

[26] I. Mohamed, N. Klauke, J. Hentschel, J. Cohen, H. Plattner, Functional and fluorochrome analysis of an exocytotic mutant yields evidence of store-operated $\mathrm{Ca}^{2+}$ influx in Paramecium, J. Membr. Biol. 187 (2002) 1-14

[27] N. Stelly, J.P. Mauger, G. Kéryer. M. Claret, A. Adoutte, Cortical alveoli of Paramecium: a vast submembranous calcium compartment. J. Cell Biol. 113 (1991) 103-112.

[28] S. Länge. N. Klauke, H. Plattner, Subplasmalemmal $\mathrm{Ca}^{2+}$ stores of probable relevance for exocytosis in Paramecium. Alveolar sacs share some but not all characteristics with sarcoplasmic reticulum, Cell Calcium 17 (1995) 335-344.

[29] M. Hardt, H. Plattner, Sub-second quenched-flow/X-ray microanalysis shows rapid $\mathrm{Ca}^{2+}$ mobilization from cortical stores paralleled by $\mathrm{Ca}^{2+}$ influx during synchronous exocytosis in Paramecium cells, Eur. J. Cell Biol. 79 (2000) 642-652.

[30] K. Hauser, N. Pavlovic, R. Kissmehl, H. Plattner, Molecular characterization of a sarco(endo)plasmic reticulum $\mathrm{Ca}^{2+}$-ATPase gene from Paramecium tetraurelia and localization of its gene product to sub-plasmalemmal calcium stores, Biochem. J. 334 (1998) 31-38.

[3I] R. Kissmehl, S. Huber, B. Kottwitz, K. Hauser, H. Plattner, Subplasmalemmal Ca-stores in Paramecium tetraurelia. Identification and characterisation of a sarco(endo)plasmic reticulum-like $\mathrm{Ca}^{2+}$-ATPase by phosphoenzyme intermediate formation and its inhibition by caffeine, Cell Calcium 24 (1998) 193-203.

[32] H. Plattner, M. Flötenmeyer, R. Kissmehl, N. Pavlovic, K. Hauser, M. Momayezi, N. Braun. J. Tack, L. Bachmann, Microdomain arrangement of the SERCA-type $\mathrm{Ca}^{2+}$ pump ( $\mathrm{Ca}^{2+}$-ATPase) in subplasmalemmal calcium stores of Paramecium cells, J. Histochem. Cytochem. 47 (1999) 841-853.

[33] K. Hauser, N. Pavlovic, N. Klauke, D. Geissinger, H. Plattner, Green fluorescent protein-tagged sarco(endo)plasmic reticulum $\mathrm{Ca}^{2+}$-ATPase overexpression in Paramecium cells: isoforms, subcellular localization, biogenesis of cortical calcium stores and functional aspects. Mol. Microbiol. 37 (2000) 773-787.

[34] F.W. Johenning, B.E. Ehrlich, Signaling microdomains: Ins $\mathrm{P}_{3}$ receptor localization takes on new meaning, Neuron 34 (2002) 173-178.

[35] C. Montell, L. Birnbaumer, V. Flockerzi, The TRP channels, a remarkably functional family, Cell 108 (2002) 595-598.

[36] Y.J. Wang, R.B. Gregory, G.J. Barritt, Maintenance of the filamentous actin cytoskeleton is necessary for the activation of store-operated $\mathrm{Ca}^{2+}$ channels, but not other types of plasma-membrane $\mathrm{Ca}^{2+}$ channels, in rat hepatocytes, Biochem. J. 363 (2002) 117-126.

[37] M. Poenie, D. Epel. Ultrastructural localization of intracellular calcium stores by a new cytochemical method, J. Histochem. Cytochem. 35 (1987) 939-956.

[38] M. Hardt, H. Plattner, Quantitative energy-dispersive X-ray microanalysis of calcium dynamics in cell suspensions during stimulation on a subsecond time scale: preparative and analytical aspects as exemplified with Paramecium cells, J. Strucl. Biol. 128 (1999) 187-199.

[39] R.D. Allen, A.K. Fok. Modulation of the digestive lysosomal system in Paramecium caudatum. III. Morphological effects of cytochalasin B. Eur. J. Cell Biol. 37 (1985) 35-43.

[40] H. Kersken, M. Momayezi, C. Braun, H. Plattner, Filamentous actin in Paramecium cells: functional and ultrastrucutral changes correlated with phalloidin affinity labeling in vivo, J. Histochem. Cytochem. 34 (1986) 455-465.

[41] H. Kersken, J. Vilmart-Seuwen, M. Momayezi, H. Plattner, Filamentous actin in Paramecium cells: mapping by phalloidin affinity labeling in vivo and in vitro, J. Histochem. Cytochem. 34 (1986) 443-454 
[42] J. Cohen, N. Garreau De Loubresse. J. Beisson, Actin microfilaments in Paramecium: localization and role in intracellular movements. Cell Motil. 4 (1984) 443-468.

[43] A.K. Fok, S.S.-K. Leung, D.P. Chun. R.D. Allen, Modulation of the digestive lysosomal system in Paramecium caudatum. II. Physiological effects of cytochalasin B. colchicine and trifluoperazine, Eur. J. Cell Biol. 37 (1985) 27-34.

[44] J. Beisson, M. Rossignol, Movements and positjoning of organelles in Paramecium aurelia, in: S. Puiseux-Dao (Ed.), Nucleocytoplasmic Relationships During Cell Morphogenesis in Some Unicellular Organisms, Elsevier, Amsterdam, New York, London, 1975, pp. 291-294.

[45] R.V. Zackroff, L.A. Hufnagel, Relative potencies of different cytochalasins for the inhibition of phagocytosis in ciliates, J. Eukaryot. Microbiol. 45 (1998) 397-403.

[46] N. Klauke, H. Plattner, "Frustrated exocytosis"-a novel phenomenon: membrane fusion without contents release, followed by detachment and reattachment of dense core vesicles in Paramecium cells, J. Membr. Biol. 176 (2000) 237-248.

[47] C. Erxleben, H. Plattner, $\mathrm{Ca}^{2+}$ release from subplasmalemmal stores as a primary event during exocytosis in Paramecium cells, J. Cell Biol. 127 (1994) 935-945.

[48] H. Plattner, A. Habermann. R. Kissmehl, N. Klauke, I. Majoul, H.-D. Söling, Differential distribution of calcium stores in Paramecium cells. Occurrence of a subplasmalemmal store with a calsequestrin-iike protein, Eur. J. Cell Biol. 72 (1997) 297-306.

[49] F. Saitow, Y. Nakaoka, Y. Oosawa, A calcium-activated, large conductance and non-selective cation channel in Paramecium cell, Biochim. Biophys. Acta 1327 (1997) 52-60.

[50] X. Wang, S. Reznick, P. Li, W. Liang. C. Van Breemen, $\mathrm{Ca}^{2+}$ removal mechanisms in freshly isolated rabbit aortic endothelial cells, Cell Calcium 31 (2002) 265-277.
[51] H. Mogami, J. Gardner. O.V. Gerasimenko, P. Camello, O.H. ] tersen, A.V. Tepikin. Calcium binding capacity of the cytosol c endoplasmic reticulum of mouse pancreatic acinar cells, J. Physi 518 (1999) 463-467.

[52] C. White, G. McGeown, Imaging of changes in sarcoplasmic rel ulum $\left[\mathrm{Ca}^{2+}\right]$ using Oregon Green BAPTA $5 \mathrm{~N}$ and confocal laser scanning microscopy, Cell Calcium 31 (2002) 151-159.

[53] M.J. Logan-Smith, P.J. Lockyer, J.M. East, A.G. Lee, Curcumin, a molecule that inhibits the $\mathrm{Ca}^{2+}$-ATPase of sarcoplasmic reticulum but increases the rate of accumulation of $\mathrm{Ca}^{2+}$, J. Biol. Chem. 276 (2001) 46905-46911.

[54] C. Franzini-Armstrong, The sarcoplasmic reticulum and the control of muscle contraction, FASEB J. 13 (Suppl.) (1999) \$266-S270.

[55] A.V. Somlyo, H Gonzales-Serratos, H. Shuman. G. McClellan, A.P. Somlyo, Calcium release and ion changes in the sarcoplasmic reticulum of tetanized muscle: an electron-probe study. J. Cell Biol. 90 (1981) 577-594.

[56] P. Hellstrand, Role of the sarcoplasmic reticulum in smooth muscle, BioEssays 24 (2002) 483-484.

[57] S. Länge, J.-D. Wissmann, H. Plattner, Caffeine inhibits $\mathrm{Ca}^{2+}$ uptake by subplasmalemmal calcium stores ('alveolar sacs') isolated from Paramecium cells, Biochim. Biophys. Acta 1278 (1996) 191-196.

[58] K.A. Joiner, D.S. Roos, Secretory traffic in the eukaryotic parasite Toxoplasma gondii: less is more, J. Cell Biol. 157 (2002) 557-563.

[59] T. Harumoto, A. Miyake, Defensive function of trichocysts in Paramecium. J. Exp. Zool. 260 (1991) 84-92.

[60] G. Knoll, B. Haacke-Bell, H. Plattner. Local trichocyst exocytosis provides an efficient escape mechanism for Paramecium cells, Eur. J. Protistol. 27 (1991) 381-385.

[61] R. Pape, H. Plattner, Synchronous exocytosis in Paramecium cells. V. Ultrastructural adaptation phenomena during re-insertion of secretory organelles, Eur. J. Cell Biol. 36 (1985) 38-47. 